\title{
COMMERCIALLY AVAILABLE ORGANIC MANURES ON THE GROWTH, YIELD AND NUTRIENT CONTENT OF BURMESE GRAPES (Baccaurea ramiflora)
}

\author{
Munna, M. R., S. A. Trisa, M. M. Islam, M. J. Islam, D. C. Pal and M. K. Rahman \\ Department of Soil, Water and Environment, University of Dhaka, Dhaka-1000, Bangladesh
}

\begin{abstract}
A pot experiment was carried out in the net house of the Department of Soil, Water and Environment, University of Dhaka to evaluate the effectS of different organic manures on the growth performance, biomass production, NPKS content in leaf, stem and root of Burmese grapes (Baccaurea ramiflora) and some chemical properties of post- harvest soil. Two-month old Burmese grapes seedlings were planted in different organic manure-treated soils (viz. ACI, BGF, Bhola, Green Life, Kazi, Modern, Mazim, Payel, Payel Earth, and Shebok). A significant variation was observed among the treatments. Compared to control treatment, application of organic manures exhibited a significant influence on the physiological growth, viz. plant height $(30.4-34.06 \mathrm{~cm})$, leaf area $\left(64.2-71.30 \mathrm{~cm}^{2} / \mathrm{plant}\right)$, leaf area index $(0.17-0.19)$, fresh weight $(32.2-53.06$ $\mathrm{g} / \mathrm{plant}$ ), and dry weight (22.09 - $41.24 \mathrm{~g} / \mathrm{plant})$ after 120 days of the experiment. The highest plant height, leaf area, leaf area index, fresh weight, and dry weight were recorded in Kazi, BGF, Payel and Payel Earth, respectively. Similarly, the concentrations of N, P, K, and S in leaf, stem and root, and their uptakes were found significantly higher than the control. The highest N, P, K and S uptake by leaf, stem and root ranged from $37.66-41.69 \mathrm{~kg} / \mathrm{ha}, 0.70-0.92 \mathrm{~g} / \mathrm{ha}, 66.19-84.926 \mathrm{~kg} / \mathrm{ha}$ and $6.82-10.11 \mathrm{~kg} / \mathrm{ha}$, respectively. Protein content was the highest in Payel in leaf $(8 \%)$ and root $(5 \%)$, and stem $(7 \%)$ in Modern manure treatment. The overall results revealed that Kazi and Payel manures might be better for raising strong and healthy Burmese grape seedlings.
\end{abstract}

Key words: Burmese grapes; Organic manure; Yield; Growth; Nutrient concentration.

\section{INTRODUCTION}

Burmese grapes locally known as Lotkon, belong to the family Euphorbiaceae. This tree is generally a medium-sized, slow-growing evergreen tree that reaches up to $15-25 \mathrm{~m}$ in height and $25-70 \mathrm{~cm}$ in diameter with a short trunk and a broad crown (van Sam et al. 2004). It grows in sandy and granite soils, but it succeeds in a wide range of well-drained to wetter soils. It is commercially cultivated for its fruits which is pretty popular among the people of all ages in Bangladesh. The Burmese grapes are increasingly cultivated in the Narsingdi, Gazipur, Manikgonj, Sylhet, and Netrokona districts of Bangladesh (Rahman et al. 2014). The farmers are already profiting handsomely from the cultivation of Burmese grapes. Burmese grapes pulp is consumed raw. This innovative food additive is abundant in vitamin $\mathrm{C}$, protein, and iron. In addition, this underappreciated fruit can be used to make jam and jelly, as well as wine (Hossain et al. 2017). Moreover, a valuable dye called annatto is also produced from its seeds. Orange annatto dye is found in about $4.8-6 \%$ of seeds and is used to color silk, cotton, and other textiles (Abdullah et al. 2005).

Modern research supports its use as a traditional medication and its therapeutic benefits. According to Prodhan and Mridu (2021), it can aid in bone health, energy, a healthy pregnancy, muscular health, immunity, and weight loss, among other things. Fruit juice is mainly used to treat constipation and is also used medicinally to treat skin disease. The whole plant of $B$. ramiflora is used as an antiinflammatory and anodyne in Chinese Dai medicine to heal injuries such as rheumatoid arthritis, cellulitis, and abscesses (Lin et al. 2003). Peter (2008) stated that B. ramiflora fruit is recognized as a unique food ingredient due to its high vitamin $\mathrm{C}$, protein and iron content. Moreover, the bark, roots, and wood are stored for medicinal uses (Islam et al. 2010). The Burmese grape is an underutilized fruit crop, 
and very little research is available on its advantages and physico-chemical features (Deb and Bhowmick 2013).

The use of organic manures is drawing increasing attention from researchers worldwide. Organic manures help limit concurrent environmental degradation and regenerate environmentally degraded areas (Chen 2006). Besides, environment-friendly organic manures application improves soil structure, promotes microbial activities, enhances crop nutrient utilization efficiency (NUE), and reduces the negative impact of pesticides (Bhatta et al. 2009). Several researchers have noted that although bacterial populations were different in different soils, nutrients available for plant absorption increased quickly in the experimental soil after organic manure application (Prodhan and Mridu 2013). Islam et al. (2010) reported that the application of organic manure would increase crop yield and improve soil quality, especially soil organic matter content, which is a vital soil element that affects soil biological and soil chemical properties (Bhardwaj et al.2011). Therefore, this study was conducted to determine the influence of different organic manures on growth, biomass production, nutrient and protein content in leaf, stem and root of the Burmese grape in the net house of the Department of Soil, Water and Environment, University of Dhaka.

\section{MATERIAL AND METHODS}

Soil samples (0-15 cm depth) were collected from Sreenagar under Munshigonj district. The location

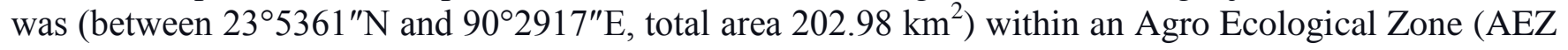
12) with Low Ganges River Flood Plain and land type is Medium Low Land. The soil predominately includes Calcareous Dark Grey soils and Calcareous Brown Floodplain soils (BARC 2018). The collected soil was air-dried, crushed, sieved through a $2 \mathrm{~mm}$ stainless steel sieve, and stored for physicochemical analysis and pot experiment. Some physical and chemical properties of the soil are presented in Table 1.

Table 1. Some physical and chemical properties of the soil used.

\begin{tabular}{lcc}
\hline Soil properties & Values & Analytical methods \\
\hline $\mathrm{pH}$ & 6.45 & Soil: Water $=1: 2.5$ (Jackson 1962) \\
$\mathrm{EC}(\mu \mathrm{S} / \mathrm{m})$ & 53.4 & Soil: Water $=1: 5$ (Jackson 1962) \\
Organic carbon $(\%)$ & 0.60 & Walkley and Black (1934) \\
Organic matter $(\%)$ & 1.036 & \\
Total nitrogen $(\%)$ & 0.15 & Marr and Cresser (1983) \\
Total phosphorus $(\%)$ & 0.07 & Olsen et al. $(1954)$ \\
Total potassium $(\%)$ & 0.01 & Pratt (1965) \\
Soil moisture content $(\%)$ & 16.51 & Bouyoucos (1962) \\
Sand $(\%)$ & 26.57 & \\
Silt $(\%)$ & 57.56 & \\
Clay $(\%)$ & 15.87 & \\
Soil texture & Silty loam & \\
\hline
\end{tabular}

Seedlings were collected from a nursery, Farmgate, Dhaka, Bangladesh. Manures were supplied by ten different companies, viz. ACI, BGF, Bhola, Green Life, Kazi, Modern, Mazim, Payel, Payel Earth, and Shebok. A pot experiment was carried out in the net house of the Department of Soil, Water and Environment, University of Dhaka. Seven kilograms of air-dried soil was mixed properly with $72 \mathrm{~g}$ of organic manure (6-ton $\left.\mathrm{ha}^{-1}\right)$ on a clean polythene sheet and placed in a $10 \mathrm{~kg}$ pot $(22 \mathrm{~cm}$ diameter and 30 cm height).

A seedling (two months old) was planted in each pot, and water was supplied every day for one week following plantation to support initial rooting. The experimental pots contained holes at the bottom 
to drain out irrigated and rainwater. The pots were arranged in a completely randomized design (CRD) with three replications, and a control treatment was also set up without manure. The height, number of leaves, and leaf area were measured at every 15 days' interval. The height of the individual plant was calculated from the soil surface to the tip of the leaf. Leaf area was determined following Kayode and Tedela (2005) method: $\mathrm{A}=\mathrm{L} \times \mathrm{B} \times 0.75$, Where $\mathrm{A}$ is the length of the leaf, $\mathrm{B}$ is the breadth of the leaf, and 0.75 is constant.

Burmese grapes were harvested after 120 days of transplantation. All the plant parts were washed with tap water and distilled water to remove ions and any adhering particles and wrapped with soft tissue paper. The plant samples were separated using scissors into three parts- leaf, stem, and root. Immediately after harvest, the fresh weight of leaf, stem, and root was recorded. Samples were air-dried at room temperature for three days and finally oven-dried at $65^{\circ} \mathrm{C}$ for 72 hours (Islam et al. 2020). Dry weight was recorded, ground in a mechanical grinder, and stored in air-tight plastic bottles for chemical analysis. For total nitrogen, $0.2 \mathrm{~g}$ of sample was digested in a Kjeldahl digestion flask (Marr and Cresser 1983), for P, K, and $\mathrm{S}$ determination their samples were digested in di-acid $\left(2: 1\right.$ ratio of $\mathrm{HNO}_{3}$ and $\left.\mathrm{HClO}_{4}\right)$ as per the method of AOAC (1990). Phosphorus of the digest was determined by the vanadomolybdophosphoric yellow color method in the nitric acid system at $430 \mathrm{~nm}$ using a spectrophotometer (model DR 5000) (Jackson 1962). Potassium in the digest was determined by using JENWAY flame photometer (model PFP 7). The total S content of the digest was determined by the turbidimetric method (Hunt 1980) at a wavelength of $420 \mathrm{~nm}$. From the chemical analytical data, uptake of each nutrient was calculated as shown below:

Nutrient uptake $(\mathrm{kg} / \mathrm{ha})=\frac{\text { Nutrient content }(\%) \times \text { dry weight }(\mathrm{kg} / \mathrm{ha})}{100}$

The percent protein content in leaf, stem and root of Baccaurea ramiflora was determined by multiplying per cent nitrogen in leaf, stem and root by 6.25 according to Magomya et al. (2014).

Analysis of variance was done with the help of SPSS program and the mean differences among different treatments were evaluated by LSD test at 5\% level. The significant difference among treatments was compared by the least significant difference (LSD) at $5 \%$ level of probability.

\section{Effects of manures on growth}

\section{RESULTS AND DISCUSSION}

The plant height, leaf number, leaf area, and leaf area index are summarized in Table 2. The application of organic manures had a significant effect on the physiological growth of Baccaurea ramiflora Lour. Height, leaf area, and leaf area index increased from 30 to 120 days of plantations (Plate 1). Height showed significant variation among the treatments after 90 and 120 days, while leaf numbers were similar except after 120 days. On the contrary, the leaf area showed significant variation among the 11 applied manures from 30 days to 120 days. The maximum values of these four parameters were recorded in Kazi after 120 days of the experiment. Although the initial heights of Bhola and Green life treatments were smaller than the controls, they exceeded the control height after 120 days, indicating the positive effects of organic manures on plant growth. ACI and Mazim showed the highest number of leaves (11 leaves/plant), and control had the lowest leaves production (8 leaves /plant). The maximum leaf area was $71.28 \mathrm{~cm}^{2}$ obtained in Kazi, and the lowest value was $54.73 \mathrm{~cm} 2$ observed in control treatments. The minimum leaf area index of 0.144 was determined in the control treatments. Leaf area index was determined from the value of leaf area and soil area and expressed as leaf area per unit surface of the soil and characterizes plant canopies. The enhanced plant development in response to organic manure application is well-known exhibiting a significant steady increase in plant growth due to the improved nutrient conditions in the root rhizosphere (Diacono and Montemurro 2011). Seedlings began to sprout new leaves after plantation, and leaf number increased gradually. 


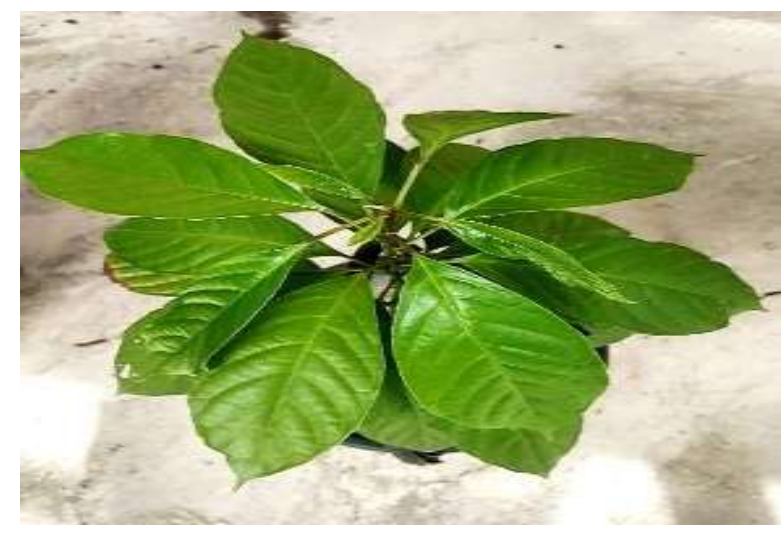

a.

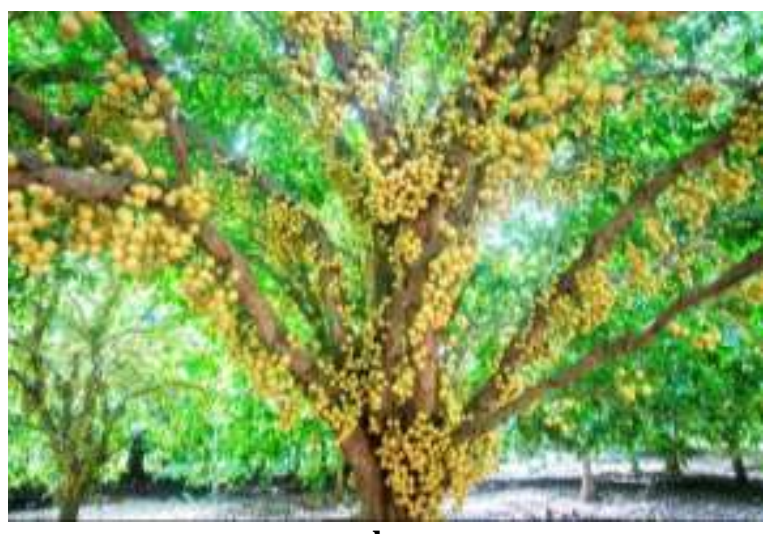

b.

Fig. 1. Burmese grapes (Lotkon in Bengali) grown in Bangladesh: a. Seedling grown in Payel manure; and b. Burmese Grapes appeared on the tree.

Naturally, organic manure mineralization provides the organic matters and nutrient elements to soils that are used for plant growth. However, the mineralization process takes a long time and releases nutrients more slowly but stores them longer in the soil (Ayoola and Makinde 2009). With time, the nutrients from organic fertilizers support rapid plant leaf formation and root development (Baldi et al. 2010).

Table 2. Effects of different manures on height, leaf number, leaf area and leaf area index of Baccaurea ramiflora.

\begin{tabular}{|c|c|c|c|c|c|c|c|c|c|c|c|c|c|c|c|c|}
\hline \multirow{2}{*}{$\begin{array}{l}\text { Treatments } \\
\left(6 \text { ton } \mathrm{ha}^{-1}\right)\end{array}$} & \multicolumn{4}{|c|}{ Height (cm) } & \multicolumn{4}{|c|}{ Leaf number } & \multicolumn{4}{|c|}{ Leaf area $\left(\mathrm{cm}^{2}\right.$ plant $\left.^{-1}\right)$} & \multicolumn{4}{|c|}{ Leaf area index } \\
\hline & 30d & 60d & 90d & 120d & 30d & 60d & 90d & 120d & 30d & 60d & 90d & 120d & 30d & 60d & 90d & 120d \\
\hline Control & 20.7 & 23.5 & 25.6 & 27.6 & 4 & 5 & 7 & 8 & 18.4 & 31 & 49.5 & 54.7 & 0.05 & 0.08 & 0.13 & 0.14 \\
\hline $\mathrm{ACI}$ & 22.15 & 24.1 & 26.4 & 31.16 & 4 & 5 & 7 & 10 & 22.8 & 34.1 & 57.7 & 67.2 & 0.06 & 0.09 & 0.15 & 0.18 \\
\hline BGF & 23.2 & 26.6 & 29.7 & 32.5 & 4 & 4 & 7 & 10 & 24 & 35.7 & 59.1 & 71.2 & 0.06 & 0.09 & 0.16 & 0.19 \\
\hline Bhola & 18.4 & 20.3 & 23.9 & 30.4 & 4 & 5 & 7 & 10 & 21.3 & 33.5 & 50.7 & 64.2 & 0.06 & 0.09 & 0.13 & 0.17 \\
\hline Green Life & 20.5 & 24.5 & 29.2 & 32.9 & 4 & 5 & 7 & 10 & 21.2 & 33 & 58.1 & 65.6 & 0.06 & 0.09 & 0.15 & 0.17 \\
\hline Kazi & 24.8 & 27.8 & 31.5 & 34.06 & 4 & 5 & 7 & 11 & 23.4 & 35.8 & 60.9 & 71.3 & 0.06 & 0.09 & 0.16 & 0.19 \\
\hline Modern & 22.5 & 25.3 & 27.9 & 30.6 & 4 & 5 & 7 & 9 & 22.2 & 34.1 & 58.1 & 65.4 & 0.06 & 0.09 & 0.15 & 0.17 \\
\hline Mazim & 20.8 & 26.2 & 29.6 & 31.9 & 5 & 5 & 8 & 11 & 22.3 & 34.5 & 58.5 & 68.4 & 0.06 & 0.09 & 0.15 & 0.18 \\
\hline Payel & 23.2 & 26.5 & 29.8 & 32.01 & 4 & 5 & 7 & 10 & 23.4 & 35.8 & 60.2 & 70.5 & 0.06 & 0.09 & 0.16 & 0.19 \\
\hline Payel Earth & 22.1 & 26.5 & 28.5 & 31.4 & 4 & 4 & 7 & 10 & 23.2 & 35.4 & 59.1 & 69.3 & 0.06 & 0.09 & 0.16 & 0.18 \\
\hline Shebok & 24.5 & 27.6 & 30.02 & 32.1 & 4 & 4 & 6 & 9 & 23.7 & 35.6 & 58.4 & 68.1 & 0.06 & 0.09 & 0.15 & 0.18 \\
\hline LSD at $5 \%$ & NS & NS & 4.47 & 3.82 & NS & NS & NS & 1.2 & 2.51 & 2.26 & 4.01 & 3.46 & - & - & - & - \\
\hline
\end{tabular}

Fresh and dry weight of leaf, stem and root

There was a significant difference $(\mathrm{p}<0.05)$ among the treatments regarding the fresh weight and dry weight (leaf, stem, and root) of B. ramiflora. The highest value of the leaf's fresh and dry weight was (11.87 g/plant and $10.73 \mathrm{~g} / \mathrm{plant})$ found in Payel. Payel earth showed the highest fresh and dry weight of both stem (14.60, 12.80, respectively) and root treated soil (28.49, $20.59 \mathrm{~g} / \mathrm{plant}$, respectively). Payel showed maximum total fresh weight and dry weight that were $53.06 \mathrm{~g} / \mathrm{plant}$ and $41.24 \mathrm{~g} / \mathrm{plant}$, respectively. Contrary, ACI showed the total lowest fresh value that was $32.2 \mathrm{~g} / \mathrm{plant}$, and the total lowest dry value, $22.09 \mathrm{~g} / \mathrm{plant}$ (Table 3). The total fresh and dry weight of all the treatments was significantly higher than the control treatment indicating that organic manure greatly affects the physiological growth of Burmese grapes. According to Ayeni and Oye (2017), organic manures boost 
plant growth features such as plant height, number of leaves, shoots per plant, and fresh root and shoot weights.

Table 3. Effects of different organic manures on the fresh and dry weight of Baccaurea ramiflora.

\begin{tabular}{l|cccc|cccc}
\hline \multirow{2}{*}{$\begin{array}{l}\text { Treatments } \\
\text { (6 ton/ha) }\end{array}$} & \multicolumn{3}{|c|}{ Fresh weight $\left(\mathbf{g ~ p l a n t}^{\mathbf{- 1}}\right)$} & \multicolumn{4}{c}{ Dry weight $\left(\mathbf{g ~ p l a n t}^{\mathbf{- 1}}\right)$} \\
\cline { 2 - 8 } Control & Leaf & Stem & Root & Total & Leaf & Stem & Root & Total \\
\hline ACI & 5.45 & 6.56 & 10.84 & 12.62 & 3.49 & 5.07 & 6.17 & 14.73 \\
BGF & 7.48 & 10.21 & 14.51 & 32.2 & 5.8 & 8.14 & 8.15 & 22.09 \\
Bhola & 10.55 & 13.37 & 27.18 & 51.1 & 9.37 & 11.89 & 11.02 & 32.28 \\
Green Life & 7.66 & 8.8 & 21.43 & 37.89 & 6.03 & 7.36 & 12.78 & 26.17 \\
Kazi & 10.49 & 11.32 & 21.56 & 43.37 & 9.05 & 9.91 & 12.92 & 31.88 \\
Modern & 8.06 & 10.27 & 16.69 & 35.02 & 7.12 & 8.95 & 9.49 & 25.56 \\
Mazim & 9.48 & 8.43 & 19.61 & 37.52 & 8.16 & 6.85 & 11.38 & 26.39 \\
Payel & 11.58 & 11.15 & 20.91 & 43.64 & 10.67 & 9.65 & 12.61 & 32.93 \\
Payel Earth & 11.87 & 13.4 & 27.79 & 53.06 & 10.73 & 11.25 & 19.26 & 41.24 \\
Shebok & 7.91 & 14.6 & 28.49 & 51 & 6.51 & 12.8 & 20.59 & 39.9 \\
\hline LSD at 5\% & 7.96 & 12.3 & 16.04 & 36.3 & 6.57 & 10.44 & 9.19 & 26.2 \\
\hline
\end{tabular}

Concentrations of $N, P, K$ and $S$ in leaf, stem and root

The concentrations of nitrogen in the leaf, stem, and root of Burmese grapes were affected by different levels of organic manures. Data in Table 4 illustrated that nitrogen concentration in Burmese grapes leaf, stem, and root at different organic manures treatments varied significantly $(\mathrm{p}<0.05)$. The nitrogen concentration ranged from 0.89 to $1.36 \%$ in leaf, 0.80 to $1.31 \%$ in stem and 0.44 to $0.83 \%$ in root. The maximum nitrogen concentrations in leaf and root were $1.36 \%$ and $0.83 \%$, respectively recorded in Payel, and stem was $1.31 \%$ determined in Modern. The minimum nitrogen concentrations of leaf, stem, and shoot were $1.16,0.43$, and $0.86 \%$, respectively found in ACI treatments.

Table 4. Effects of organic manures on $\mathrm{N}, \mathrm{P}, \mathrm{K}$ and $\mathrm{S}$ concentrations in the leaf, stem and root of Baccaurea ramiflora.

\begin{tabular}{l|ccc|ccc|ccc|ccc}
\hline Treatments & \multicolumn{3}{|c|}{$\mathbf{N}(\%)$} & \multicolumn{3}{c|}{$\mathbf{P}(\%)$} & \multicolumn{3}{c|}{ K $(\%)$} & \multicolumn{3}{c}{$\mathbf{S}(\%)$} \\
\cline { 2 - 12 } & Leaf & Stem & Root & Leaf & Stem & Root & Leaf & Stem & Root & Leaf & Stem & Root \\
\hline Control & 0.89 & 0.8 & 0.44 & 0.02 & 0.015 & 0.01 & 1.5 & 1.12 & 0.9 & 0.02 & 0.06 & 0.077 \\
ACI & 1.16 & 0.86 & 0.43 & 0.021 & 0.016 & 0.011 & 2.15 & 1.49 & 1.16 & 0.24 & 0.11 & 0.079 \\
BGF & 1.2 & 1.12 & 0.47 & 0.028 & 0.019 & 0.013 & 2.52 & 1.65 & 1.23 & 0.35 & 0.22 & 0.084 \\
Bhola & 1.28 & 1.05 & 0.65 & 0.022 & 0.016 & 0.014 & 2.87 & 1.42 & 1.25 & 0.33 & 0.12 & 0.09 \\
Green Life & 1.22 & 1.13 & 0.56 & 0.027 & 0.018 & 0.014 & 2.39 & 1.65 & 1.44 & 0.34 & 0.19 & 0.094 \\
Kazi & 1.24 & 1.04 & 0.66 & 0.024 & 0.017 & 0.012 & 2.33 & 1.56 & 1.24 & 0.25 & 0.16 & 0.081 \\
Modern & 1.26 & 1.31 & 0.74 & 0.025 & 0.015 & 0.013 & 2.34 & 1.37 & 1.27 & 0.36 & 0.13 & 0.085 \\
Mazim & 1.34 & 1.16 & 0.75 & 0.031 & 0.017 & 0.016 & 2.62 & 1.56 & 1.29 & 0.27 & 0.17 & 0.087 \\
Payel & 1.36 & 1.18 & 0.83 & 0.024 & 0.019 & 0.014 & 2.77 & 1.77 & 1.34 & 0.33 & 0.21 & 0.114 \\
Payel Earth & 1.32 & 1.03 & 0.72 & 0.032 & 0.02 & 0.014 & 2.26 & 1.81 & 1.41 & 0.38 & 0.23 & 0.116 \\
Shebok & 1.31 & 0.94 & 0.65 & 0.023 & 0.018 & 0.012 & 2.34 & 1.63 & 1.23 & 0.31 & 0.2 & 0.085 \\
\hline LSD at 5\% & 0.1 & 0.21 & 0.055 & 0.0003 & 0.0002 & 0.0001 & 0.13 & 0.16 & 0.14 & 0.024 & 0.006 & 0.014 \\
\hline
\end{tabular}

The highest concentration value of phosphorous of leaf and stem were $0.032 \%$, and $0.020 \%$, respectively showed by Payel Earth, and root was $0.016 \%$ shown by Mazim. The lowest concentration value of leaf and root were $0.021 \%$ and $0.011 \%$, respectively measured in ACI, and the stem was 0.015 $\%$, as shown by Modern. The concentrations of $\mathrm{K}$ in leaf, stem, and root varied between 2.15 and 2.87 $\%, 1.37$ and $1.81 \%$, and 1.16 to $1.44 \%$, respectively. The maximum concentration of Sulphur in leaf and stem was $0.38 \%$ and $0.23 \%$, respectively (Payel Earth), and root was $0.094 \%$ (Green Life). While 
the minimum concentration of $\mathrm{S}$ in leaf, stem, and root were $0.24 \%, 0.11 \%$, and $0.079 \%$, respectively recorded in ACI treatment (Table 4).

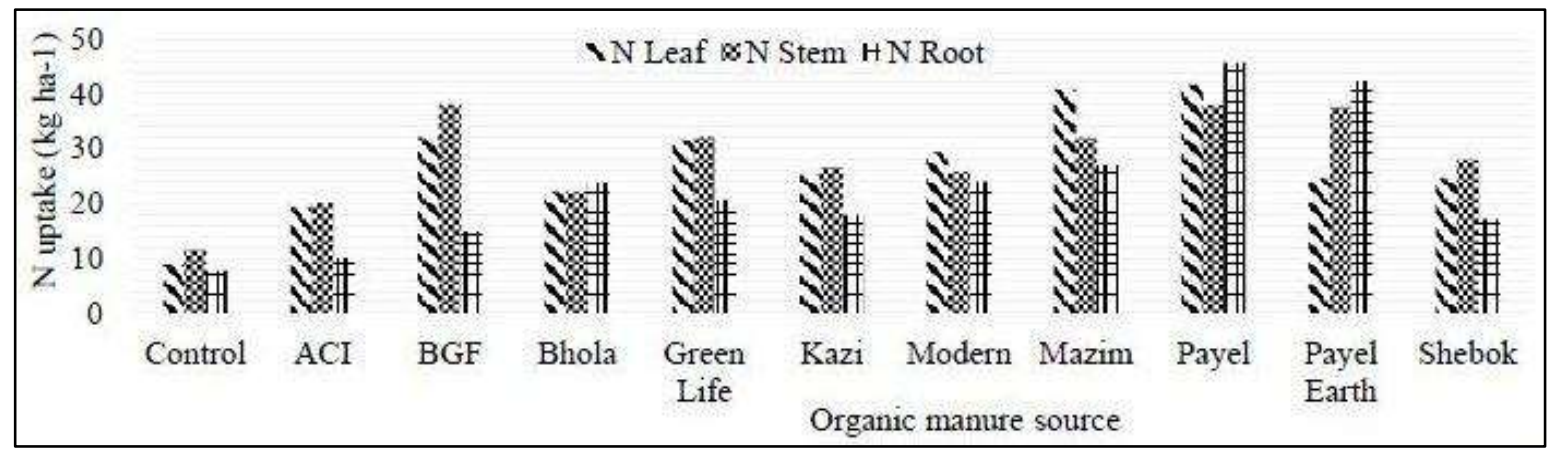

a.

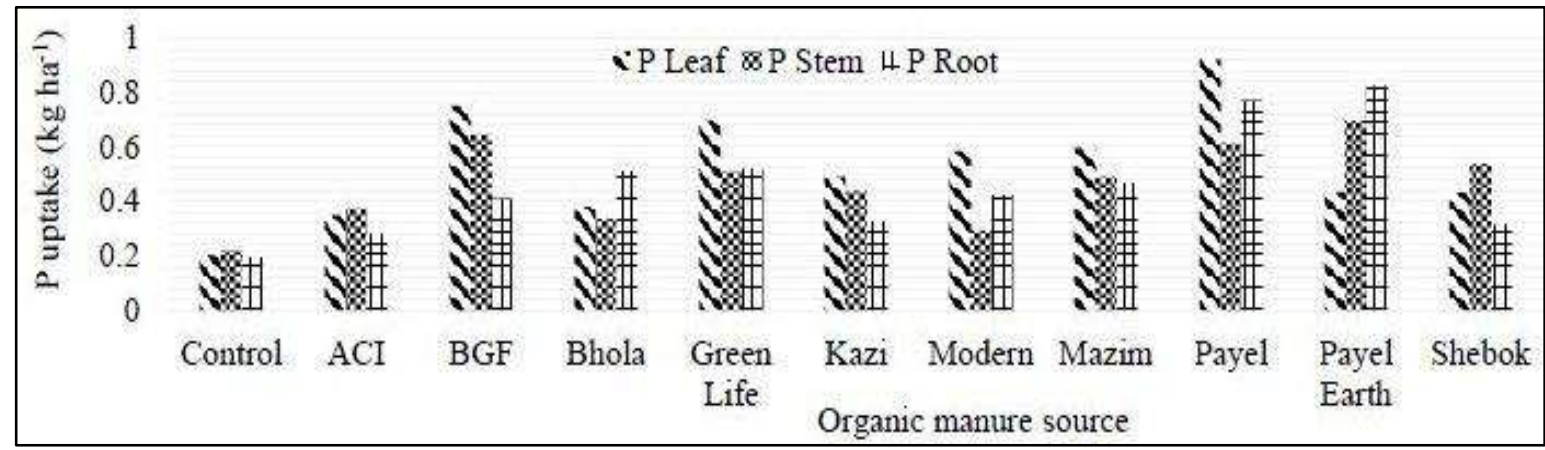

b.

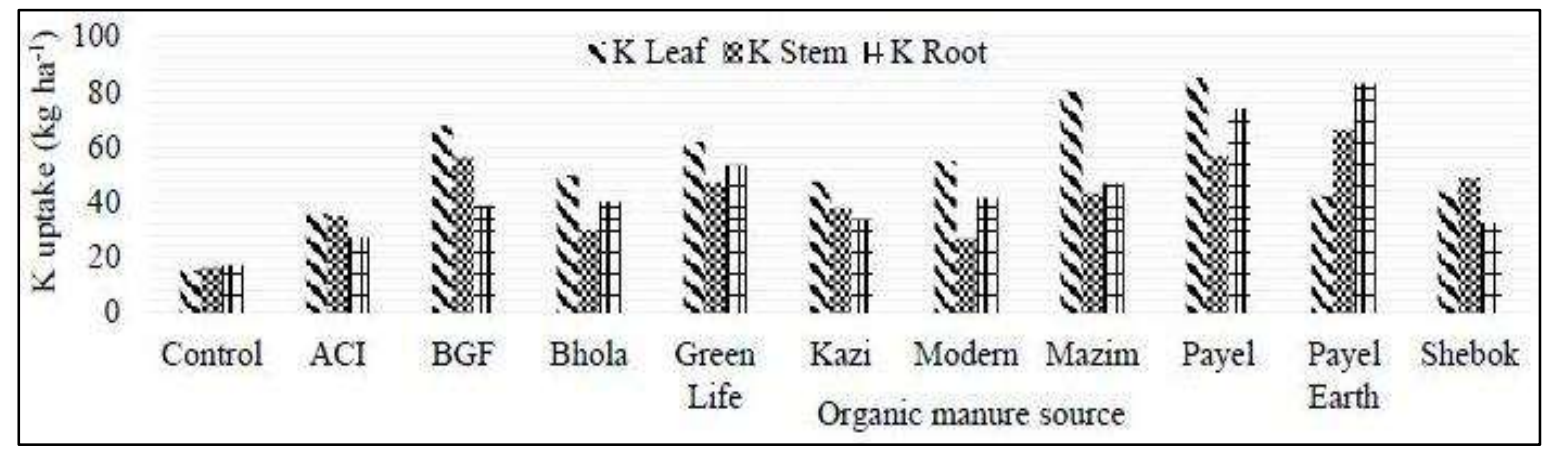

c.

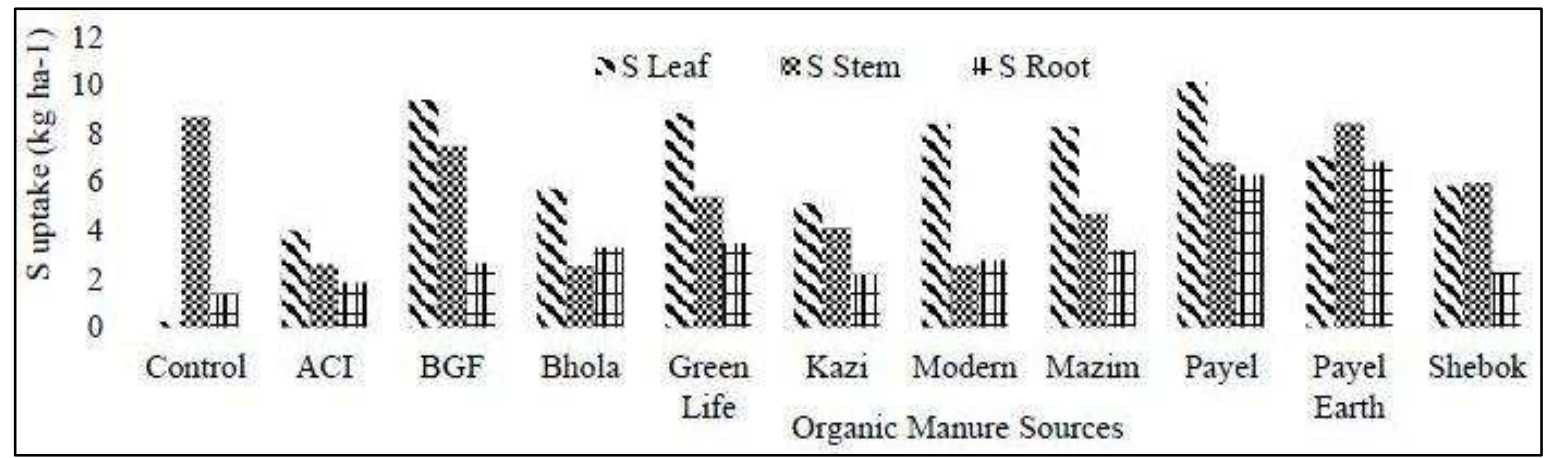

d.

Fig. 2. Effects of different organic manures on: a. N; b. P; c. K; and d. S uptake by leaf, stem and root of Burmese grapes. 
The addition of manure to the soil could improve the organic matter content, ultimately improving soil structure while increasing nutrient availability. Organic matter availability affects crop growth and yields both directly by giving nutrients and indirectly by altering soil physical qualities, such as aggregate stability and porosity, promoting root growth, rhizosphere, and plant growth (Goss et al. 2013). In fields alternating sorghum (Pennisetum glaucum) and wheat (Triticum aestivum), Kaur et al. (2005) mentioned that organic manure boosted soil concentrations of organic carbon, nitrogen, phosphorus, and potassium, underlining its importance in tropical farmland, which lacks these nutrients. Murmu et al. (2013) observed that organic manure boosts crop yield, nitrogen usage efficiency, and soil health in acidic soil when compared to chemical fertilizer on tomatoes (Lycopersicon esculentum) and maize (Zea mays).

There is a significant difference between the control experiment and other treatments in respect of nutrient uptake by plants (Fig. 2). The average nutrients uptake by the plants ranged from 8.875 to 41.69 $\mathrm{kg} /$ ha for N, 15.50 to $30.30 \mathrm{~kg} / \mathrm{ha}$ for P, 72.8 to $166 \mathrm{~kg} / \mathrm{ha}$ for K and 1.84 to $8.41 \mathrm{~kg} / \mathrm{ha}$ for S (Fig. 2). The maximum N, P, and K uptakes were found in Payel treatments, whereas $\mathrm{S}$ was determined in Payel Earth. Munir et al. (2007) also suggested that organic fertilizer has a favorable effect because it boosts plant nutrient uptake efficiency by increasing water holding capacity and granulated soil structure. As a result, organic manure can be an excellent supply of nitrogen, phosphorus, potassium and sulfur.

Organic manures have a greater positive impact on soil quality than inorganic fertilizers, resulting in increased nutrient release and availability to plants. The presence of poultry manure aids the soil in keeping a larger rate of administered urea intact or in the form of ammonium ions in the soil for a longer period of time, resulting in higher nitrogen uptake efficiency. Increased soil bulk density affected tomato plant uptake of N, P, K, Ca, and Mg in Alfisols in southwestern Nigeria (Adekiya and Ojeniyi 2002). As a result of the increased soil physical qualities generated by the application of poultry manure, nutrient absorption improved.

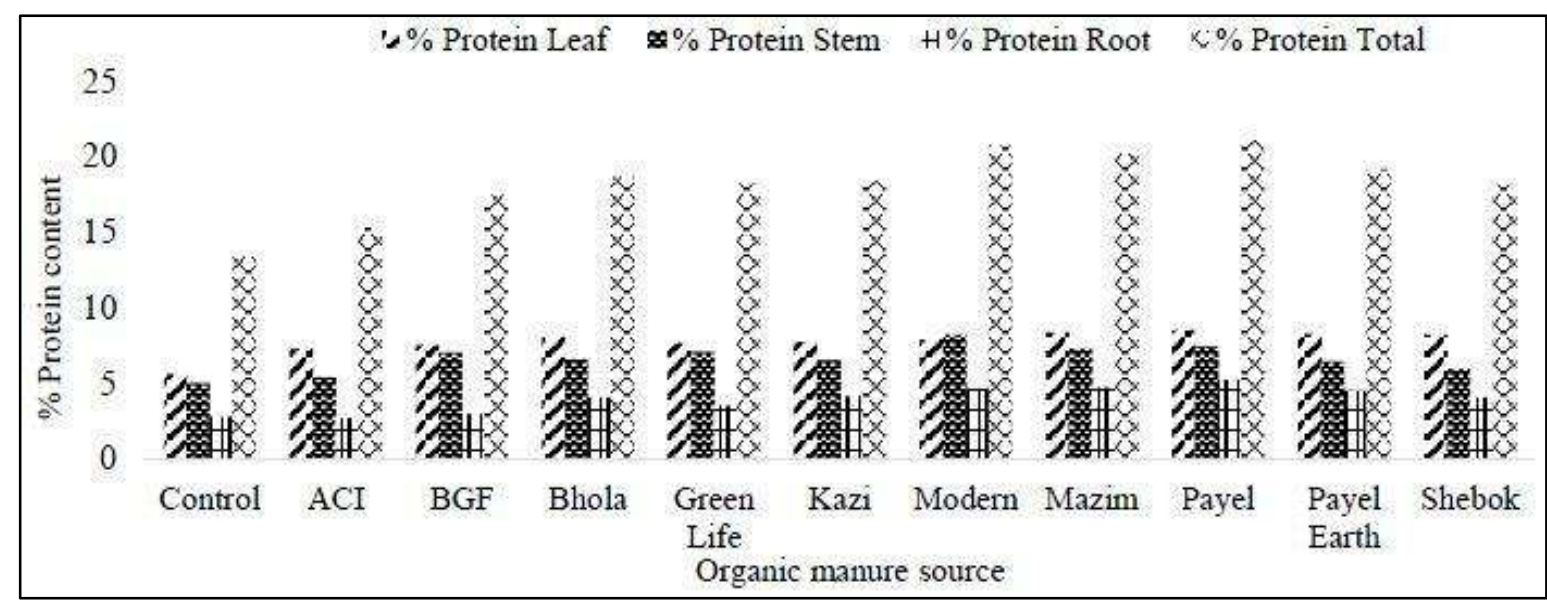

Fig. 2. Effects of different organic manures on protein content in leaf, stem, root, and total leaf, stem and root.

Protein content in leaf, stem, and root is presented in Fig. 3, where the maximum amount of protein was achieved in leaf at Payel compost (8\%), stem in Modern compost (7\%) and root in Payel compost $(5 \%)$. The highest protein content was found in the leaf and the lowest was recorded in the root. Islam et al. (2020) reported that the highest protein content in leaf $(24.65 \%)$ was achieved in $\mathrm{VC}_{15}$ ton/ha, $\mathrm{P}_{10}$ $\mathrm{kg} / \mathrm{ha}, \mathrm{K}_{20} \mathrm{~kg} / \mathrm{ha}$ in Spinacia oleracea. Magomya et al. (2014) collected ten different plants samples from the wild and farmland of Nigeria and found that protein range from 2.63 to $18.59 \%$. 


\section{Residual values of soils}

Manures contain some organic acid anions, which will consume protons during their breakdown that increase soil $\mathrm{pH}$. The $\mathrm{pH}$ of post-harvest soil (after 120 days of planting) of Control, ACI, BGF, Bhola, Green Life, Kazi, Modern, Mazim, Payel, Payel Earth, and Shebok were 6.45, 7.2, 7.15, 7.16,7.5, 7.2, 7.3, 7.32, 7.25, 7.06 and 7.35, respectively. The highest soil pH was 7.35 in Shebok, and the lowest soil pH was 6.45 in control.

Table 5. pH, EC, organic carbon and organic matter of post-harvest soil.

\begin{tabular}{lcccc}
\hline Treatment $\left(\right.$ ton $\left.\mathbf{~ h a ~}^{-1}\right)$ & $\mathbf{p H}$ & $\mathbf{E C}(\boldsymbol{\mu S})$ & Organic C $(\%)$ & Organic matter $(\%)$ \\
\hline Control & 6.45 & 53.4 & 0.65 & 1.118 \\
ACI & 7.2 & 54.7 & 1.25 & 4.59 \\
BGF & 7.15 & 87.1 & 1.69 & 1.874 \\
Bhola & 7.16 & 58.7 & 1.34 & 2.304 \\
Green Life & 7.5 & 82.8 & 1.76 & 3.027 \\
Kazi & 7.2 & 109.4 & 1.45 & 2.494 \\
Modern & 7.3 & 91.5 & 1.75 & 3.01 \\
Mazim & 7.32 & 64.2 & 1.71 & 2.15 \\
Payel & 7.25 & 70.6 & 1.81 & 3.113 \\
Payel Earth & 7.06 & 80.8 & 1.89 & 2.562 \\
Shebok & 7.35 & 82.8 & 1.01 & 1.737 \\
\hline
\end{tabular}

The electrical conductivity of Control, ACI, BGF, Bhola, Green Life, Kazi, Modern, Mazim, Payel, Payel Earth, and Shebok were 53.4, 54.7, 87.1, 58.7, 82.8, 109.4, 91.5, 64.2, 70.6, 80.8, and 82.8 $\mu$ S, respectively. Post-harvest soil analysis revealed that the soil organic matter values were higher than the initial sample. In control, the organic carbon was $0.65 \%$. Due to applying organic manure, the amount of organic carbon increased, i.e., ACI, BGF, Bhola, Green Life, Kazi, Modern, Mazim, Payel, Payel Earth, Shebok, values were $1.25,1.69,1.34,1.76,1.45,1.75,1.71,1.81,1.89$, and $1.01 \%$, respectively. Payel Earth contained the highest organic carbon, $1.89 \%$, and ACI contained the lowest organic matter, $1.25 \%$, respectively. Olanikan (2006) concluded that applying organic manure has substantial effects on plants' height, leaf number, leaf area, fresh and dry weight, and the length of root, branch number, stem girth, and uptake of nutrients plants.

Providing adequate soil nutrients through the application of organic manure is useful for enhancing soil health and Burmese grapes production. It could be concluded that Kazi and Payel organic manures might be preferable to produce strong and healthy seedlings for raising successful Burmese grapes plantations. However, more research is needed to determine the long-term impact of organic manures on Burmese grape seedlings (Lotkon) production under varying agro- climatic conditions in Bangladesh.

\section{REFERENCES}

Abdullah, A. T. M., M. A. Hossain and M. K. Bhuiyan. 2005. Propagation of Lotkon (Baccaurea sapida Muell. Arg.) by mature stem cutting. Research J. Bio. Sci. 1(2): 129-134.

Adekiva, O. N. and S. O. Ojeniyi. 2003. Comparative effectiveness of different levels of poultry manure with NPK fertilizer on residual soil fertility, nutrient uptake and yield of maize. Moor J. Agri. Res. 4(2): 191-197.

AOAC (Association of Official Analytical Chemists). 1990. Official methods of analyses. 15th ed. Association of Official Analytical Chemists. Arlington, Virginia, USA., pp. 84-85.

Ayeni, M. J. and O. V. Oye. 2017. Effect of different organic fertilizers on the growth performance of Corchorus olitorius L. IOSR. J. Agric. Vet. Sci. 10(4): 38-44. 
Ayoola, O. T. and E. Makinde. 2009. Maize growth, yield and soil nutrient changes with N-enriched organic fertilizers. African J. food. Agri. Nutrition Develop. 9(1): 580-592.

Baldi, E., M. Toselli, D. M. Eissenstat and B. Marangoni. 2010. Organic fertilization leads to increased peach root production and lifespan. Tree Physiology. 30(11): 1373-1382.

BARC (Bangladesh Agricultural Research Council). 2018. Fertilizer Recommendation Guide. BARC Soils Publication No. 49. People Press and Publication, Purana Palton, Dhaka, Bangladesh. 112 pp.

Bhardwaj, A. K., P. Jasrotia, S. K. Hamilton and G. P. Robertson. 2011. Ecological management of intensively cropped agro-ecosystems improves soil quality with sustained productivity. Agri. Eco. Environ. 140(3-4): 419-429.

Bhatta, G. D., W. Doppler and K. C. Krishna Bahadur. 2009. Potentials of organic agriculture in Nepal. J. Agri. Environ. 10: 1-14.

Bouyoucos, G. J. 1962. Hydrometer method improved for making particle size analyses of soils. Agron. J. 54(5): 464-465.

Chen, J. H. 2006. The combined use of chemical and organic fertilizers and /or bio fertilizer for crop growth and soil fertility. In: International Workshop on Sustained Management of the SoilRhizosphere System for Efficient Crop Production and Fertilizer Use. 16(20): 1-11.

Deb, P. and N. Bhowmick. 2013. Physico-chemical properties of Burmese grape (Baccaurea sapida Muell. Arg.). An underutilized fruit crop of West Bengal. Intl. J. Agri. Food Sci. Tech. 4(5): 415420.

Diacono, M. and F. Montemurro. 2011. Long-term effects of organic amendments on soil fertility. Sustainable Agriculture. 2: 761-786.

Goss, M. J., A. Tubeileh and D. Goorahoo. 2013. A review of the use of organic amendments and the risk to human health. Advances in Agron. 120: 275-379.

Hossain, M. F., M. A. Islam, S. Akhtar and M. Anwar. 2017. Nutritional value and medicinal uses of minor fruits: Burmese grape (Baccaurea ramiflora Lour.). Intl. J. Nutrition Food Sci. 6(5): 211-214.

Hunt, J. 1980. Determination of total sulphur in small amounts of plant material. Analyst. 105(1246): 8385.

Islam, M. M., S. M. Akther, S. A. Sujon, M. A. Karim and M. K. Rahman. 2020. Effects of vermicompost and PK on growth and protein content of spinach (Spinacia oleracia L.). Bangladesh J. Bot. 49(1): 141-146.

Islam, M. R., S. M. E. Rahman, M. M. Rahman, D. H. Oh and C. S. Ra. 2010. The effects of biogas slurry on the production and quality of maize fodder. Turkish J. Agri. Forestry. 34(1): 91-99.

Jackson, M. L. 1962. Soil Chemical Analysis. Prentice- Hall Inc., Englewood Cliffs, NJ, USA. 498 pp.

Kaur, K., K. K. Kapoor and A. P. Gupta. 2005. Impact of organic manures with and without mineral fertilizers on soil chemical and biological properties under tropical conditions. J. Plant Nutrition Soil Sci. 168(1): 117-122.

Kayode, J. and P. O. Tedela. 2005. Effects of irrigation frequency on growth and nodulation of Leucaena leucocephala. Pakistan J. Forestry. 554(1): 33-40. 
Lin, Y. F., Z. Yi and Y. H. Zhao. 2003. Chinese dai medicine colorful illustrations. Yunnan National Publishing House. Kunming, China. 126 pp.

Magomya, A. M., D. Kubmarawa, J. A. Ndhai and G. G. Yebpella. 2014. Determination of plant proteins via the Kjeldahl method and amino acid analysis: A comparative study. Inter. J. Sci. Tech. Res. 3(4): 68-72.

Marr, I. L. and M. S. Cresser. 1983. The lithosphere. In: Environmental Chemical Analysis. Blackie and Son Ltd. UK., pp. 155-182.

Munir, M. A., M. A. Malik and M. F. Saleem. 2007. Impact of integration of crop manuring and nitrogen application on growth, yield and quality of spring planted sunflower (Helianthus annuus L.). Pakistan J. Bot. 39(2): 441.

Murmu K., D. K. Swain and B. C. Ghosh. 2013. Comparative assessment of conventional and organic nutrient management on crop growth and yield and soil fertility in tomato-sweet corn production system. Australian J. Crop Sci. 7(11): 1617-1626.

Olanikan, P. C. 2006. Organic manures as soil amendment in eroded tropical soil of south western Nigeria. J. Trop. Soil. 5(3): 11-18.

Olsen, S. R., C. V. Cole, F. S. Wantanabe and L. A. Dean. 1954. Estimation of available phosphorus in soils by extraction with $\mathrm{NaHCO}_{3}$. USDA Circular 939, Washington, USA.

Peter, K. V. 2008. Underutilized and Underexploited Horticultural Crops. New India Publishing. p.4.

Pratt, P. F. 1965. Potassium. In: C. A. Black (ed.). Methods of Soil Analysis. Part 2. American Soc. Agron. Inc., Madison, Wisconsin, USA., pp. 1022-1030.

Prodhan, A. S. U. and F. S. Mridu. 2021. Baccaurea motleyana (Rambai): Nutritional, phytochemical, and medicinal overview. Adv. Traditional Med. pp.1-25.

Rahman, S. M. L., M. H. M. B. Bhuyan, A. A. M. M. Mustakim, J. C. Sarker and M. A. Hussain. 2014. Fruit characteristics, yield contributing characters and yield of some lotkon genotypes under northeastern region of Bangladesh. Intl. J. Sustainable Crop Product. 9(1): 8-10.

van Sam, H., K. Nanthavong and P. J. Kessler. 2004. Trees of Laos and Vietnam: A field guide to 100 economically or ecologically important species. Blumea-Biodiver. Evol. Biogeo. Plants. 49(2-3): 201-349.

Walkley, A. and I. A. Black. 1934. An examination of the Degtjareff method for determining soil organic matter, and a proposed modification of the chromic acid titration method. Soil Science. 37(1): 29-38. 